\title{
LONG-TERM AIR POLLUTION RESPONSES TO TRANSPORTATION POLICIES IN THE TEHRAN METROPOLITAN AREA
}

\author{
MANSOUR HADJI HOSSEINLOU ${ }^{1}$, SHAHAB KABIRI ${ }^{2}$
}

\begin{abstract}
Transportation networks respond differently to applied policies. The Tehran Metropolitan Area has one of the most complex networks with complex users, which has experienced many of these policies change within the past decades. In this study, some of these policies and their effect on air pollution is investigated. The goal is to pinpoint the variables which have the most effect on various transportation models and investigate how new policies should be focused. In order to do so, long-term variations of air pollution monitoring stations were analyzed. Results show that the most significant parameter that may affect air pollution is users' behavior due to the lack of a public transportation network and its level of comfort. The results of this study will be useful in developing new policies and evaluating their long-term consequences in appropriate models.
\end{abstract}

Keywords: Transportation Networks, Air Pollution, User Behaviour, Policy Analysis

\section{INTRODUCTION}

Rapid urbanization may cause different forms of environmental pollution, such as air pollution, acid rain, water pollution, land pollution, solid waste, toxic waste, and deforestation. In the metropolitan areas of developing countries, especially in Asia, the environmental problems are much greater. Because of the overwhelming scale and speed of urbanization, air pollution being the subject of

\footnotetext{
${ }^{1}$ Associate Professor, K.N.Toosi University of Technology, Civil Engineering Department, Vali-e-asr, Mirdamad, Tehran, Iran, e-mail: Mansour@kntu.ac.ir

${ }^{2} \mathrm{PhD}$. Student, K.N.Toosi University of Technology, Civil Engineering Department, Vali-e-asr, Mirdamad, Tehran, Iran, e-mail: Shahab_kabiri@mail.kntu.ac.ir
} 
interest here, has become an undeniable problem for most countries [1]. Iran, and precisely speaking the Tehran Metropolitan Area (TMA), is not an exception. Urban air pollution is generally caused by three main sectors: Industry, Household, and Transportation [2, 3]. Putting aside the first two sectors, the transportation sector seems to be the TMA's major problem [4].

Tehran Province has a population of around 12.4 million and surpassing 8.3 million in the wider metropolitan area, according to the 2012 census [5]. Trips made by this population everyday by private vehicles with low standards along with poor public transportation systems, in far distances, have changed this city to a place no one prefers to live in voluntarily. The magnitude of the health impact estimated for the TMA highlights the need for urgent action to reduce the health burden of air pollution [6-8].

In recent years, several studies have been carried out to develop methods to reduce air pollution. These have been mainly generated by the transportation sector, but differences among measuring methods and a lack of strict quality control policies in carrying out exposure assessments make it difficult to generalize and compare findings among studies [9]. The transportation sector is a complex phenomenon; that is why this sector has always needed comprehensive studies.

A useful method that in recent years has become of interest to researchers is system dynamics (SD) modeling. This approach, which seems to be able to integrate all possible variables together, suffers from one major problem: deciding which parameters should and which should not be included in the model, which is to identify system boundaries properly. Besides, deciding between different variables could not be generalized since modeling the same problem in different situations might call for different variables. Thus, it is important to know which variables play the most vital role in a system in a particular situation. Many researchers have tried to model transportation networks using SD with numerous variables [1, 10-17]. Authors believe that there are still undiscovered variables in the TMA transportation network (TMATN) which could be useful for policy and decision makers in deciding the best way to mitigate air pollution.

Among various pollutants, carbon monoxide (CO) concentrations were of interest. Even though it is claimed that TMA's CO concentration does not expose residents to risk these days [18], it is believed that this pollutant's concentration is the most proper variable to be considered in order to evaluate the effect of transportation related theories and their consequences, at least in the TMA. This belief is due to the recorded data in various parts of the city which show a close relation with the volume of vehicles in the TMATN [19]. This study is part of a more comprehensive study carried out by authors using SD modeling to evaluate long-term consequences of applied policies on transportation networks, the results of which are expected to be published soon. 
Here, mid- to long-term variations in air pollutant concentrations in various part of the TMA have been investigated to evaluate the importance level of different parameters in the transportation sector. First, a brief review of the TMA and its characteristics, along with a short description of important managerial decisions that have been made in this sector in the past decade is presented. Afterwards, recorded data from different Air Pollution Monitoring (APM) stations is discussed to see if it can lead to better understanding of what has happened in TMA. In the last section, the conclusions, a brief summary of what happens during TMA daily trips is presented and suggestions to policy makers in order to solve TMA's air pollution problem are listed.

\section{TEHRAN METROPOLITAN AREA (TMA)}

Every morning, the city wakes up and starts a new day. Over 17 million trips are made each day, of which half are made by personal cars and the rest by public transportation system. In addition, about 55 percent of daily trips are commuter and non-home-based trips [18]. Some general information, which could affect air pollution in the TMA is presented here and in the next section. Supplementary information about TMATN daily behaviors is presented along with recorded data.

\subsection{Meteorological CONDITIONS}

TMA experiences a full seasonal change during a calendar year. Warm springs, hot summers, cool autumns and, sometimes, freezing winter days are usually experienced throughout one year in the TMA. The northern region of the city, because of its higher altitude, usually experiences a cooler weather than other regions. The most probable winds are westward ones [20].

\subsection{Socio-economic PARAMETers}

Considering economic factors, moving from the south part of the city to its north more indicators of a wealthier life can be seen. That is, wealthy people are usually residents of the northern part of the city. However, aside from the things that may be different in different parts of the city, fuel price is a variable; it is equal all over the country. Always subsidized by the government in the past decades, gasoline prices have been increasing in different steps gradually to remove subsidies in this sector. Gasoline prices over the last 15 years are shown in Fig. 1. 


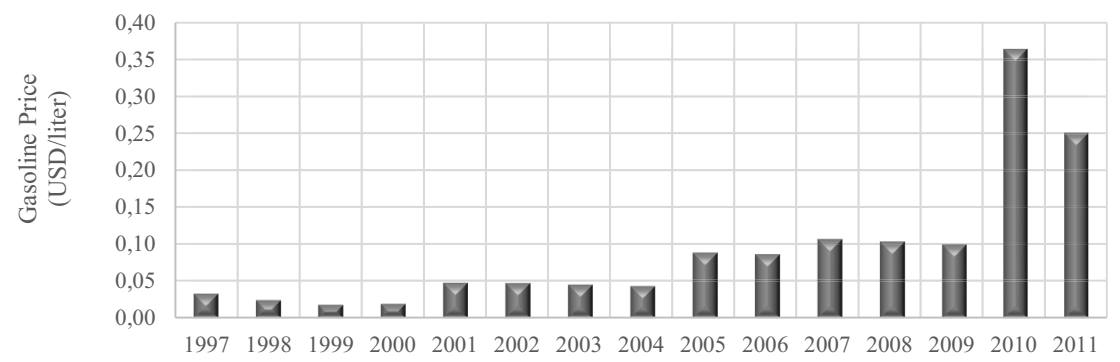

Fig. 1. Gasoline price in TMA since 1997

Another parameter, which is expected to play an important role in TMA pollution, is car ownership. The number of vehicles is more important than the vehicle speed in generating vehicular pollution [21]. If the number of existing vehicles in 2001 is neglected, the number of newly registered personal vehicles in the TMA is shown in Fig. 2.

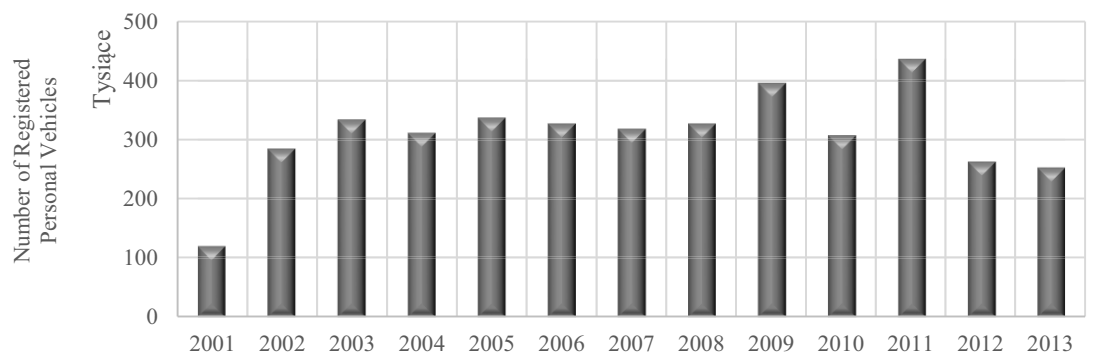

Fig. 2. Number of new registered personal Vehicles in TMA

High number of car ownership alone may be a sign of a good economy, but if not properly used (either voluntarily or otherwise), may cause irreparable damages. Besides, aged vehicles, which are beyond the scope of this study, should never be neglected because of their adverse effects on air pollution $[2,22,23]$.

\subsection{WORKING DAYS, ACADEMIC CALENDAR, AND PUBLIC HOLIDAYS}

Commuting, non-home-based, shopping, educational, and recreational trips, respectively, form $36.9 \%, 17.9 \%, 15.6 \%, 15.1 \%$ and $14.5 \%$ of Tehran daily non-return trips. While commuting and educational trips form the rush hour congestion, non-home-based, shopping, and recreational trips are more likely to be made outside the rush hour times. 
The workweek in Tehran begins on Saturday and ends on Thursday. Almost all government offices and some private owned agencies are closed on Thursdays. However, for the other agencies and offices, the working hours on Thursdays usually end at noon. That is the reason Tehran experiences a much less congested traffic on Thursdays compared to other weekdays. Working hours usually begin at 7:30am and end at 4:30pm, the times around which TMA's morning and afternoon rush hours form.

Schools open in the autumn, usually September 23 is the first day of school and June 22 is the first day of summer holidays. Thus, educational trips are eliminated between June 23 and September 22, which covers the last month of the spring and the entire summer.

There exists one national holiday in the TMA about every other week, but the longest holiday is the New Year's holiday which officially is less than a week, but in most cases lasts for almost two whole weeks. During the second week, almost all governmental offices work part time and the staff use their paid vacation days during this period. This is why this period, which starts on March 20 and ends on April 3, is locally named "Tehran Visiting Time", since you may be able to see the city with no image of traffic congestion or air pollution in the background during the day.

Based on what was described in this study, five different time periods are introduced, in which it seems that TMATN characteristics are similar. P1 period, covers March 20 until April 3, and the New Year holidays. P2 period starts on April 4 and goes until June 22 (the beginning of the summer holidays). P3 period covers all summer holidays from June 23 until September 22. P4 period, from September 23 until February 28, is when schools are closed for the New Year's holidays. P5 period covers the last days of the year from March 1 until March 20.

\subsection{Central BUSINESS DISTRICT (CBD)}

Most of the business trades during weekdays, like in almost all big cities, take place in the central part of the city. More than 40 percent of daily commuter trips (1,300,000 trips) together with 35000 commuter vehicles from adjacent towns (mostly west and south) move toward the city center in the morning peak hour [18]. That is why most transportation management policies are focused on the CBD. The region suffers from both traffic congestion and air pollution due to daily trips.

Traffic restriction plans have a long history in Tehran. The current plan, revised almost nineteen times in the coverage area, fleet and time schedule since 1978, mostly restricts personal vehicle accessibility. It was introduced in 2004. The "Odd-Even Day Traffic Restriction Policy (OETRP)" and the "Restricted Area Policy (RAP)" are two major plans applied these days. The RAP is applied in the central part of the city and has restrictions as follows: no vehicle is allowed to enter the area 
except for taxis and public buses. A limited number of daily licenses are sold separately with high prices for people who insist on using personal cars within the area. Residents of the area can have annual licenses, if interested, with lower prices. The OETRP, which is based on vehicles' license plate numbers, is self-explanatory and the area surrounded by the plan is much bigger than the area for the RAP. It is obvious that those who buy the RAP daily licenses are allowed to enter the OETRP area, regardless of their plate numbers. It is also noteworthy that based on TMA regulations, daily and annual licenses are not sold to older vehicles at all. A view of the TMA along with OETRP and RAP area is shown in Fig. 3.

\subsection{TMA AIR POLLUTION MONITORING (APM) STATIONS}

There are more than 30 APM stations installed in various regions of the TMA by the Tehran Air Quality Control Agency (TAQCA) in association with the Tehran Department of Environment (TDOE); they record pollutant concentration hourly. Unfortunately, most of these stations are newly installed stations and long-term variations could not be achieved. Data used in this study is for those stations that have longer recorded values. These stations are shown in Fig. 3. In this study, hourly concentrations have been used to obtain daily and monthly average concentrations. Microsoft Excel was used to handle data and create charts.

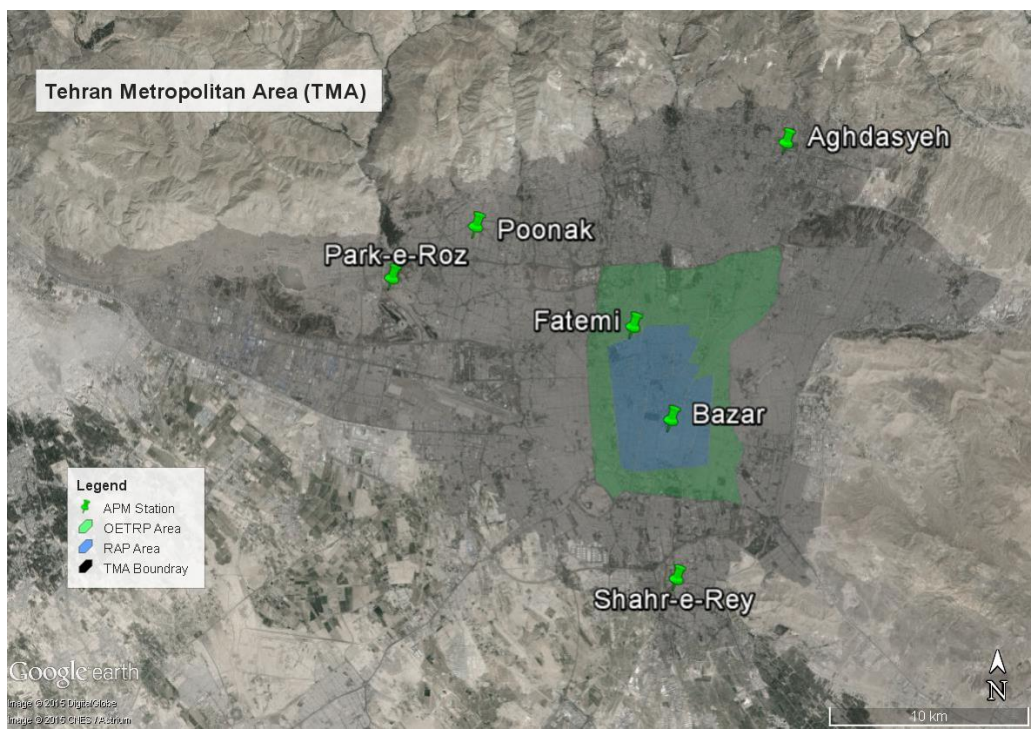

Fig. 3. Tehran Metropolitan Area 


\section{DISCUSSION - APM DATA VARIATIONS}

\subsection{LONG TERM VARIATIONS}

Fig. 4 shows long-term variations recorded by APM stations. Data regressions for almost all stations show a descending trend in CO concentrations, even slightly. Unfortunately "Bazar" and "Fatemi" stations, which were installed prior to the other stations, have stopped monitoring and it is not possible to evaluate a longer period of data variations.

One point that comes to mind is that regardless of the different time periods, which were introduced, a kind of crisis is recorded in almost all stations in 2010. This growth is also recorded in APM stations not mentioned here, all over the TMA, and will be discussed later. It is also apparent that, excluding the year 2010, the city has reached a uniform level of pollutant concentration. This may show that the city should implement new strategies to mitigate air pollution due to vehicle movements, since the current ones show they cannot do any better.

It may be concluded that since almost all stations show a smooth fall in $\mathrm{CO}$ concentrations, this fall has nothing to do with OETRP or RAP plans in the city center. Recorded data from the "Bazar" and "Fatemi" stations, which are located in CBD, show a significant reduction from 2004 to 2005. The OETRP plan was last modified in 2004, so this may be the result of the modification made to the plan. However, there is some evidence against this theory. One is that the "Bazar" station has recorded increasing values between 2007 and 2009, while it seems other affecting parameters have experienced no change.

A more precise look at gasoline prices might reveal the reason of the reduction between 2004 and 2005. The increment in gasoline prices in 2005 compared to 2004 (compared to 2004, gasoline prices in 2005 increased by 2.03 times), seems to be the reason of recorded data value decrease. But one question might arise: does this increment in price, which is also applied in 2010; a growth of 3.63 times, but, despite what seems to be logically expected, recorded data in all stations show that there is a substantial crisis in 2010. The crisis might be justified as follows: as of June 2007, a policy named the "Gasoline Rationing" plan was launched by the government in order to reduce gasoline consumption. The ration system allowed private drivers only 100 liters of fuel per month at a subsidized price. Anything more than that would have to be bought at a higher price. The prices remained constant until November 2010, but the rumors about price increases were everywhere. Those drivers who had not used their quotas until the final day, started to use their allowance. This behavior, along with the incremental growth in the number of registered vehicles in 2009 , is believed 
to be the main reason of the 2010-recorded concentrations [of air pollutants]. As of November 2010, since the price of subsidized gasoline was increased (3.63 times), an obvious fall of recorded data is visible almost everywhere in the TMA.

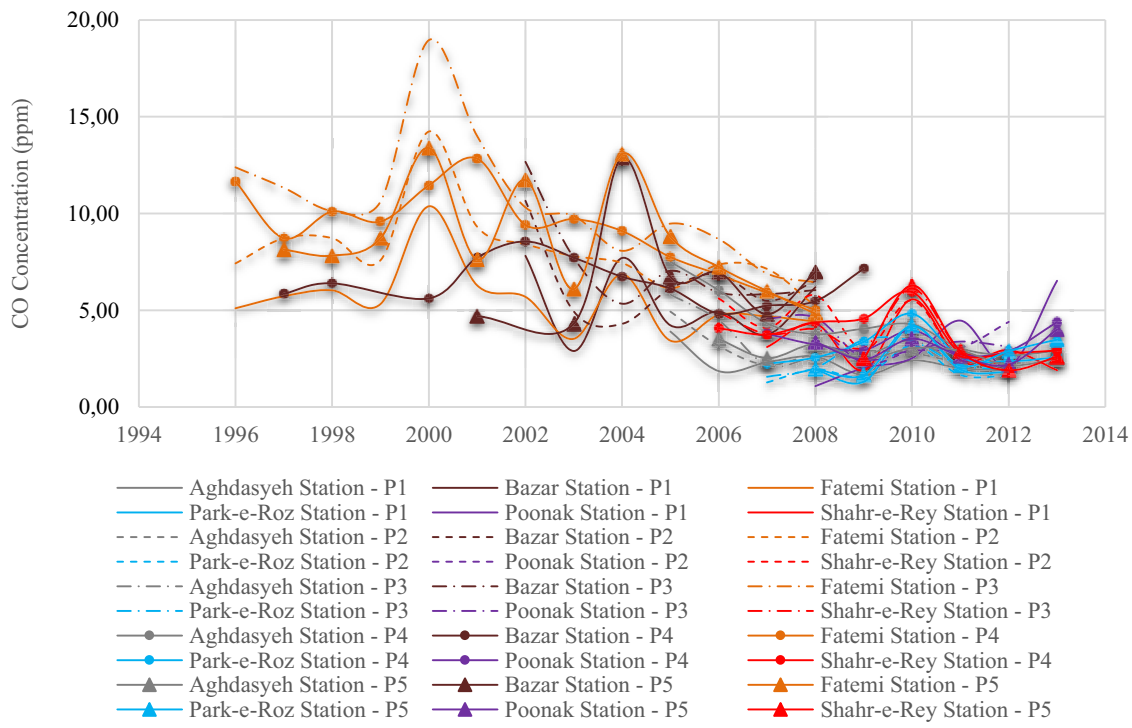

Fig. 4. APM station's data (yearly fluctuations)

In the next sections, a closer look at data variations at each station with respect to workdays and weekends across different time periods introduced before is presented.

\section{2. "BAZAR" APM STATION}

As expected, stations in CBD, where more commuters are attracted, show more differences between workday and weekend concentrations (Fig. 5). Dashed lines in the chart show the values recorded for Fridays in each year. The corresponding values for workdays and Thursdays are also plotted with similar colors for each period (P2-P5). It is visible that almost all Friday values are less than workday values and Thursday values which at this particular station behave like workdays. Actually, a reduction is not expected on Thursdays since the station is located where commuters work also on Thursdays, at least part time. If calculated, Friday values have an average of 80 percent of a workday's concentrations. P5 period, however, shows a kind of discrepancy with P2, P3, and P4 periods. It looks 
more appropriate to have the P5 period next to the P1 period as shown in Fig. 6. As it is seen, daily fluctuations of what happens in P1 and P5 periods follow a similar pattern (Note that the similar pattern discussed here is about workdays and weekends and not about annual patterns). The reason for the pattern in P1 period seems apparent since the city is on public holidays during the New Year and the CBD is almost all in the part-time working period. However, the reason for the P5 period is believed to be the shopping trips made to the CBD prior to the New Year's holidays, which are also made on weekends. The decrease in the values due to stopped shopping trips in P1 period compared to $\mathrm{P} 5$ period (which in some cases is about 40 percent) is another evidence proving this.

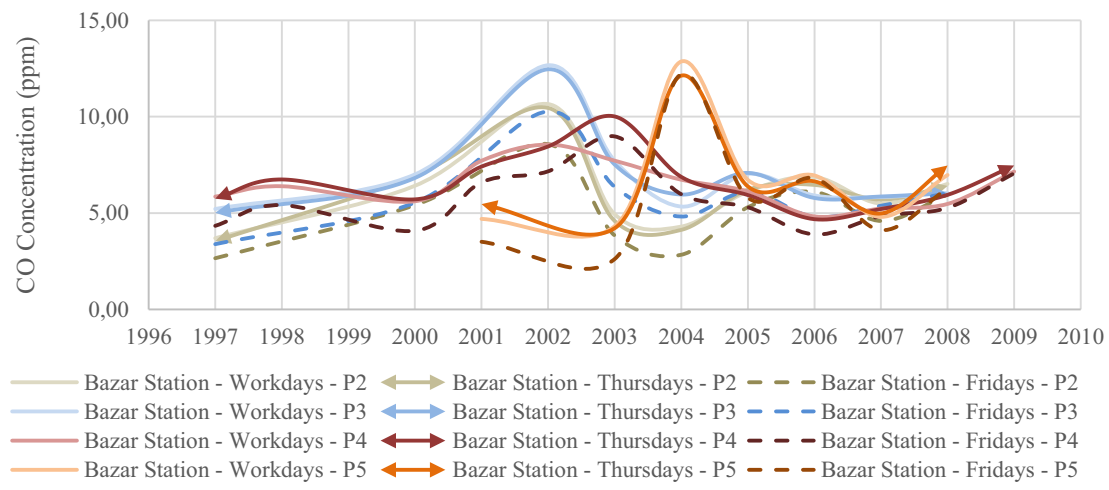

Fig. 5. "Bazar" APM station's data, P2-P5 periods

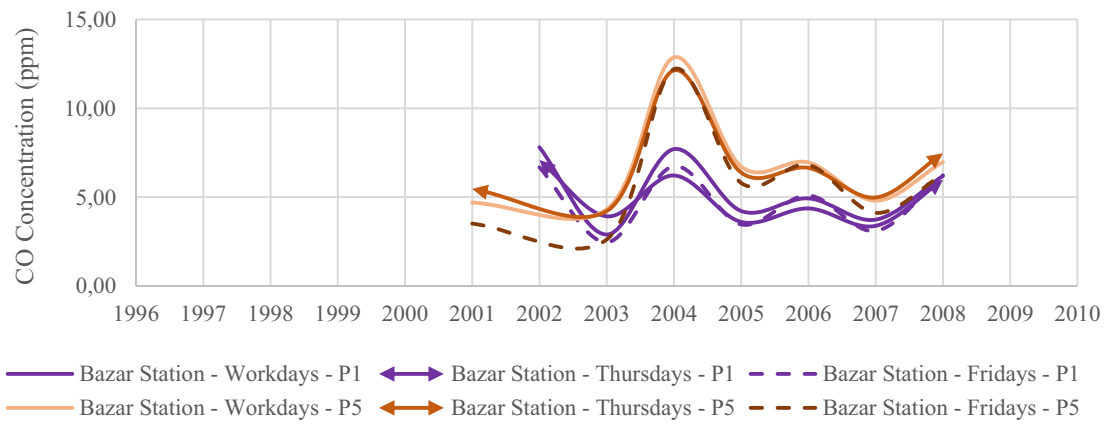

Fig. 6. "Bazar" APM station's data, P1\&P5 periods 


\section{3. "FATEMI" APM STATIONS}

What was observed for the "Bazar" station in workday and weekend values and their differences is also visible at the "Fatemi" station (Fig. 7). It is noteworthy that the "Fatemi" station is located on the boundary of the OETRP and RAP areas. Therefore, on one hand, the station is located in CBD and the region has to serve daily commuters, and on the other hand, compared to the "Bazar" station, it has the privilege of being more accessible by private cars.

More noticeable from 1997 until 2001, Fig. 8 shows that the "Fatemi" station still records greater values than the "Bazar" station in general, but the worrying thing is that both charts seem to have a kind of convergence, which might be interpreted differently. From the "Bazar" station point of view, the convergence might not be a good sign since it shows that the RAP is not as effective as it is expected to be. However, from the "Fatemi" station point of view, it could be said that the OETRP is working just as well as the RAP. The reason for such a convergence might lie within an additional reason, which has not been mentioned here before and that is how the entrances to both areas are monitored. The RAP area has been monitored by cameras installed on entrances, while the OETRP area has been controlled by police officers; which surely makes it easier for outlaws to enter it. As time has passed, more entrances in the OETRP area have been controlled by cameras and that seems to be the reason for the convergence, which is hopefully expected to keep its distance with the RAP recorded data, because if not, it could be a proof for the ineffectiveness of both policies.

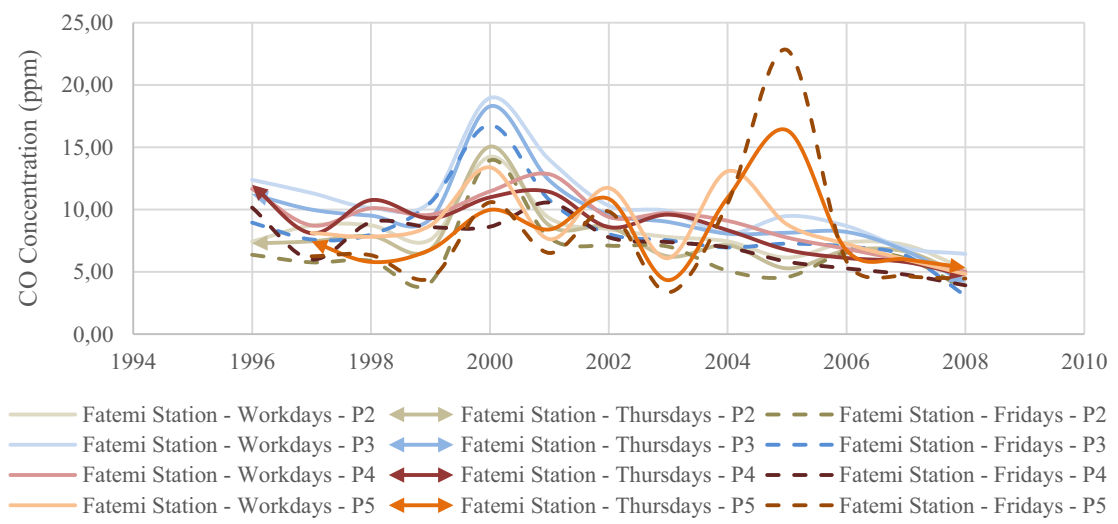

Fig. 7. "Fatemi” APM station's data, P2-P5 periods 


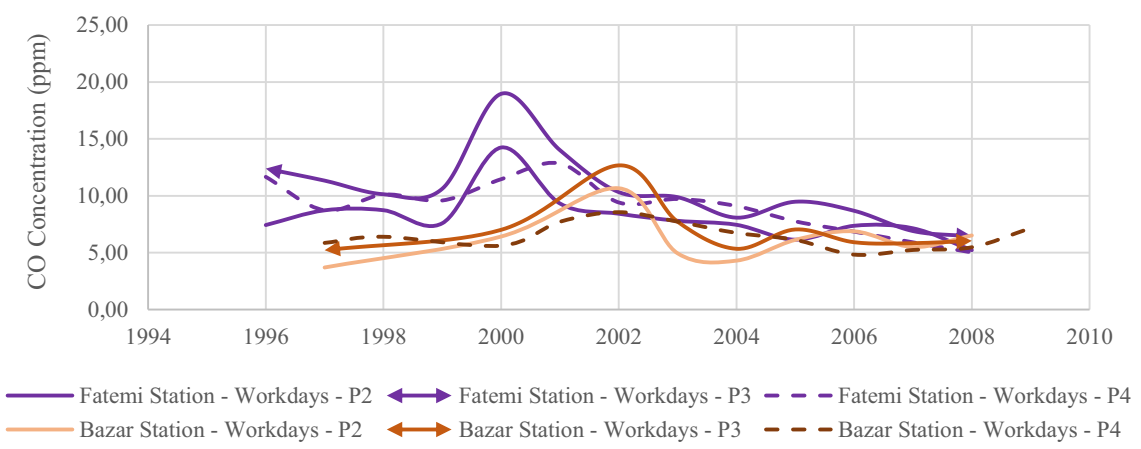

Fig. 8. "Bazar" compared to "Fatemi" APM station's data on workdays, P2-P4 periods

\section{4. "POONAK" APM STATION}

"Poonak" station has the advantage of being far from the central part of the city (The distance from this station to nearest point of the OETRP area is about $7 \mathrm{~km}$ ). The recorded crisis in 2010 and the subsequent decrease in 2011 are also recorded in this station (Fig. 9). However, the ascending behavior of data values in 2012 and 2013 is worrying. In these years, fuel quality and vehicle standards have not been decreased for sure, if anything they have increased. In addition, since different time periods show a similar trend, it might be concluded that it has nothing to do with weather conditions. The parameter, which might have shown up here, in this case is the number of daily trips. The region, compared to the $\mathrm{CBD}$, has a cleaner air, which may encourage businesses or even residents who look for a better place to be attracted. Other than cleaner air, the region has the advantage of no traffic limits for private cars. Something worse may have happened as well; as managers decide to move the offices, the staff who previously were reliant on public transportation to reach the CBD, now must use private cars because of the poor public transportation system in this region. Thus, a second crisis may be on its way in this region. It is noteworthy that the recorded concentrations for this station are at least half of what is recorded in stations located in the CBD. 


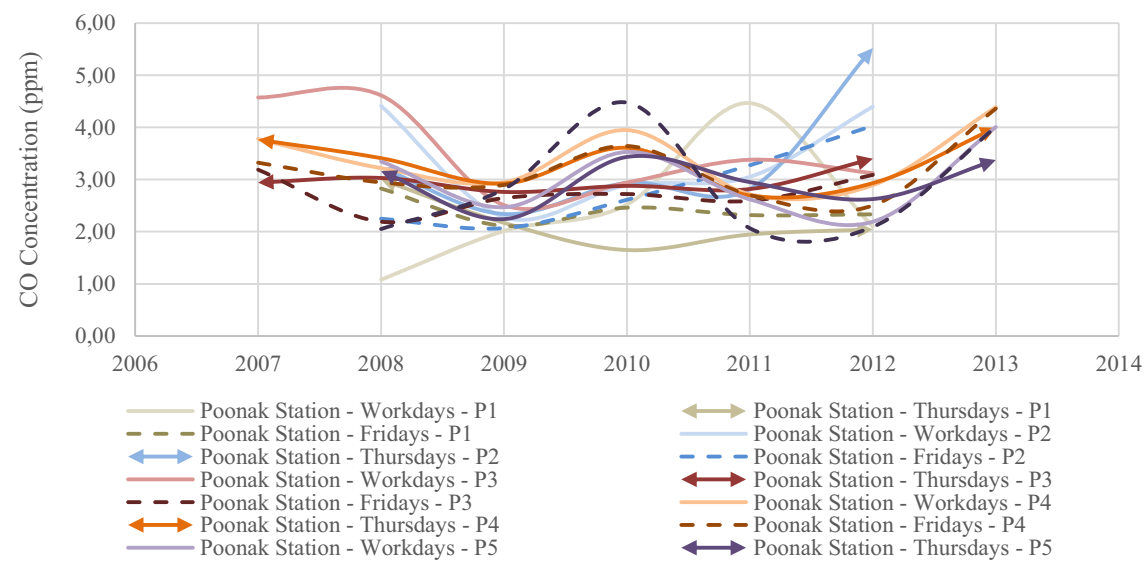

Fig. 9. "Poonak" APM station's data, P1-P5 periods

\section{5. "AGHDASYEH" APM STATION}

At the "Aghdasyeh" station, a different type of behavior is recorded. As it can be seen in Fig. 10, within each year the P4 period data values are noticeably higher than in all other periods. To justify such a behavior some parameters mentioned before are discuss-able at the "Aghdasyeh" station. This station is located in the north part of the city, and as it was described earlier, this station experiences a cooler weather. The P4 period includes the autumn and winter seasons. The first thing that comes to mind is that the greater average for $\mathrm{P} 4$ period may be due to the inversion that occurs in the winter. For such a hypothesis to be true, it seems logical that first, such an increase be visible in similar stations, and second, the greater values be recorded for the winter since the inversion happens mostly in the winter in Tehran. For similar stations, the "Poonak" station, which was discussed earlier, is the nearest to the "Aghdasyeh" station and such an increase in P4 period is not visible there for sure. To compare the difference between autumn and winter data, two other periods were defined and the data was plotted in one chart next to P4 period (Fig. 11). In this chart, P6 and P7 periods represent autumn and winter, respectively.

As it is seen, no noticeable difference between P6 and P7 periods is distinguishable, especially between 2009 and 2013. Therefore, the connection between the greater recorded values of concentrations and the inversion is off the table. Beside weather conditions, fuel quality, engine standards, or even the type of cars cannot be of any issue, because this data is recorded in each particular year separately with the same manner. The only variable that remains is the number of trips 
made by personal cars within this period. Here is an explanation for what may have happened: almost all the residents of this region are wealthy people of the city. Car ownership in this region is relatively high. Besides, this region lacks a proper public transportation network.

To be clearer, it is necessary to mention something about rainy days of the TMA here. On TMA's rainy days, a real traffic jam is visible in almost all highways and local streets of the city. The reason lies in a loop created by the behavior of taxis and private car users. When raining, everyone prefers to use his/her private car, and that is why morning commuters who ordinarily use public transportation, if feel a rainy day ahead, prefer to use personal cars instead. Traffic congestion on streets increases, and then taxis either stop working, or they demand higher charges from passengers due to the congestion (in some cases a 15-minute daily trip may become a 3-hour boring one). That is why daily commuters of the public transportation network are stuck in the streets in rainy days because taxis are not available, or if available, they demand higher charges because of congested streets. In this loop, Tehran rainy/snowy days become worse day by day. This problem behaves in different ways in various parts of the city. The central part of the city has the advantage of a better public transportation network, which consists of buses and a subway system. Taxi users can switch to buses or the subway if taxis are not available, although they will not receive any modal comfort since these systems have to serve many more passengers on these days, but at least they can get to work and back home. In the northern parts of the city, however, the solution lies within using private cars since there are no buses or subway systems. This is what the authors believe to be the reason of increased pollution in $\mathrm{P} 4$ period at the "Aghdasyeh" station. This behavior is also visible at the "Parke-Roz" station, which has similar conditions to the "Aghdasyeh" station. "Park-e-Roz" station's data is shown in Fig. 12. 


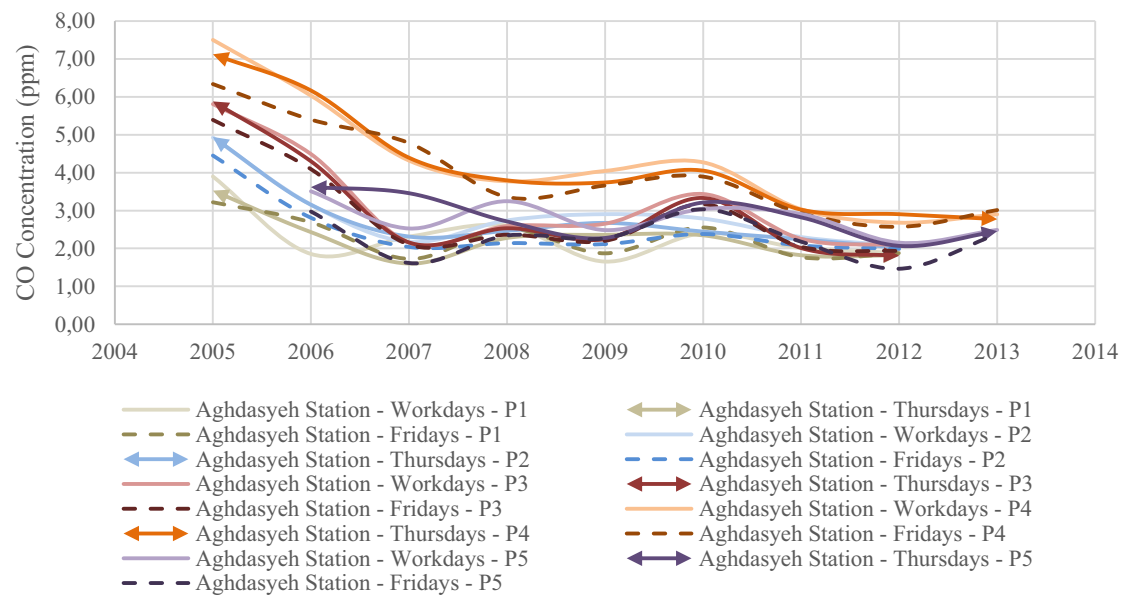

Fig. 10. "Aghdasyeh” APM station's data, P1-P5 periods

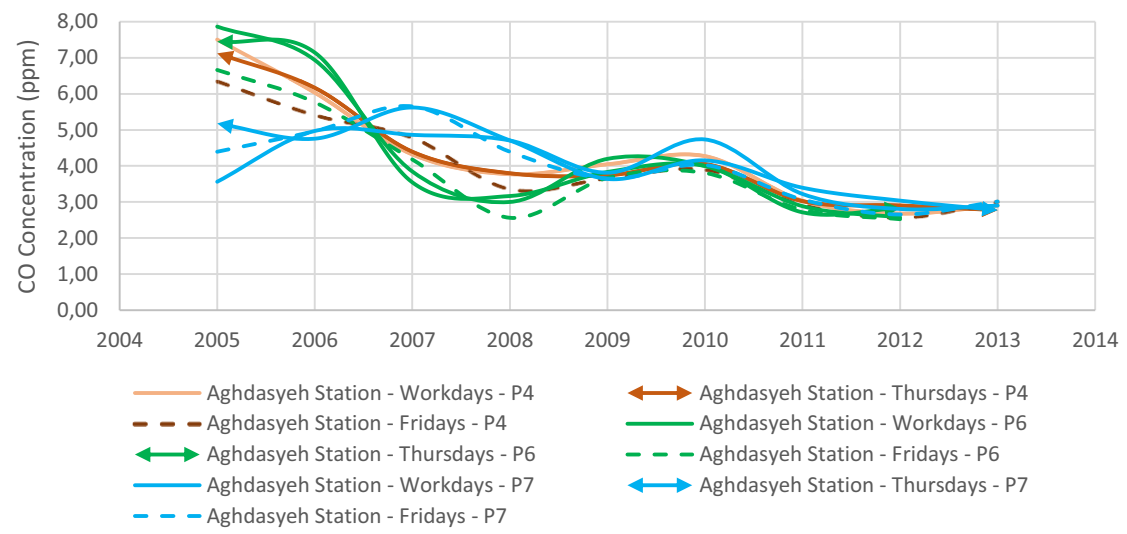

Fig. 11. "Aghdasyeh” APM station's data, P4, P6\&P7 periods

\section{6. "PARK-E-Roz" APM STATION}

As it was discussed before, in $\mathrm{P} 4$ period, this station has recorded higher values than the other periods (Fig. 12). However, something else in this station draws attention; no recognizable difference between workdays and weekends exists. Therefore, there must have been some additional trips on weekends, which replace typical workday trips. This is justifiable by considering that the station is located in a 
recreational region, which attracts many people on weekends and holidays. As it can be seen, excluding the 2010 data, the averages of the values recorded are less than what is recorded for the "Aghdasyeh" station. The smaller values could be justified by considering that the "Par-e-Roz" region has a smaller population density and subsequently has less commuters. However, the increase in year 2010, more than what was seen at the "Aghdasyeh" station, might be a consequence of the growth in car ownership, which results in attracting more people to the recreational region, especially on weekends.

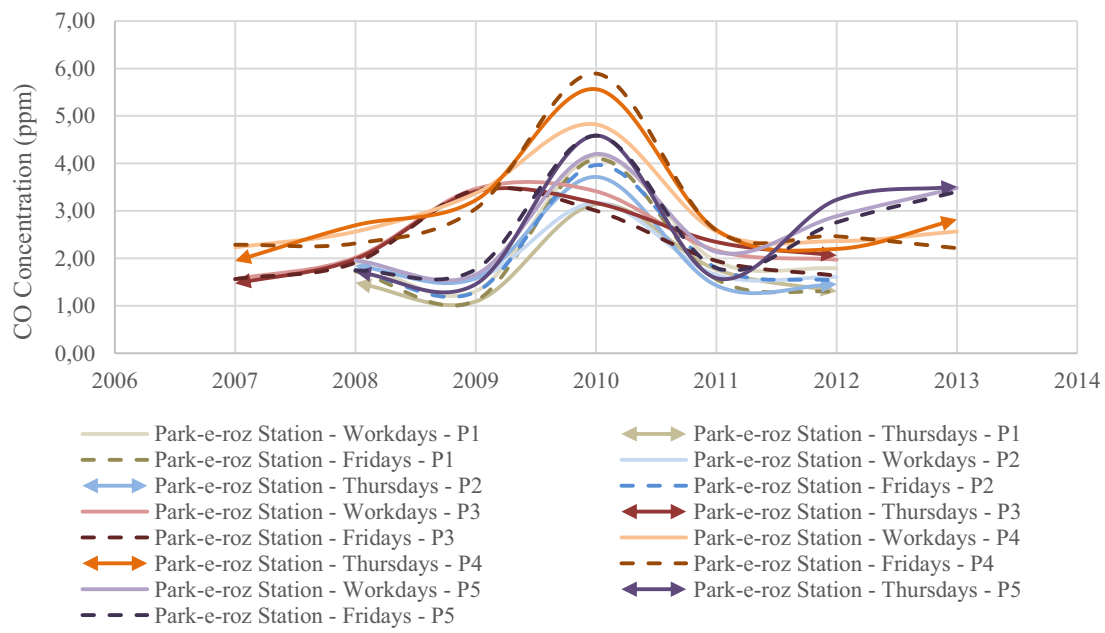

Fig. 12. "Park-e-Roz" APM station's data, P1-P5 periods

\section{7. "SHAHR-E-REY” APM STATION}

This station is located in the southern part of the city. The region belongs to moderate and below moderate people who usually cannot afford to buy vehicles, especially the ones with high standards. However, something different in this station is noticed (Fig. 13). If it is believed that the 2010 crisis is a matter of car ownership growth along with fuel price, in the years after, regardless of the day and period, all recorded data moves towards a kind of convergence. In this particular case, authors believe that something might have changed in driving habits. The drivers, who were public transportation users might have switched to personal cars instead because of the higher level of comfort. Besides, this station shows a more significant reduction in the values in 2011 with respect to 2010 values and 
compared to the other stations. The values in this station in 2010 have actually decreased by $70 \%$ in 2011, while this value for the "Park-e-Roz" and the "Aghdasyeh" stations is $50 \%$ and $30 \%$, respectively. This might be proof of the 2010 fuel price increase and its direct relation to residents' level of wealth in the coverage area of each station.

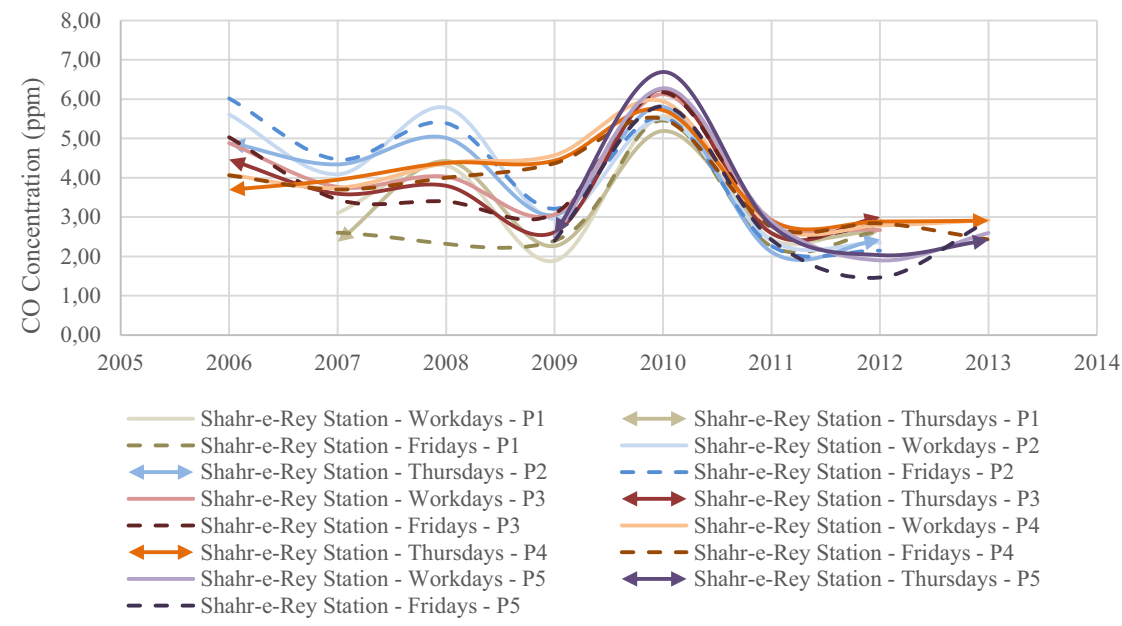

Fig. 13. "Shahr-e-Rey" APM station's data, P1-P5 periods

\section{CONCLUSIONS}

Almost a decade has passed since the last time that the major applied traffic restrictions on the TMATN were revised. New recorded values show that the CBD has reached a constant level of pollutant concentration, thus, in order to mitigate air pollution generated by the transportation sector in this region, new policies must be developed.

Data variations in various parts of the TMA show that each region has its own characteristics, which in some cases vary substantially, compared to other regions. Some of these characteristics, which have been mentioned in this study, are:

- One major variable that has been able to mitigate air pollution has proven to be the fuel price.

Almost all parts of the city, either poor or rich, have responded to fuel price increases, although not equally. 
- Wealthy residents of the city prefer to use their personal cars if they feel a reduction in comfort level in the public transportation system.

- High car ownership and its incremental growth in the last decade has led to a change of drivers' behaviors. It seems that due to a poor public transportation system, driving personal cars has become of drivers' interest.

- Another thing that seems obvious is that in the TMA, driving time has become less important in recent years. In other words, drivers usually do not get tired of driving cars in congested highways. This behavior also is surely a consequence of a poor public transportation system, which is not able to offer a level of comfort that can attract passengers.

- Data variations in less polluted areas shows a slight ascending trend. The reason might lie within the fact that the $\mathrm{CBD}$ is experiencing a kind of expansion, which might not be well-organized and may lead to a crisis in air pollution in near future.

Surely, in recent years, the level of comfort offered by public transportation to passengers has increased. However, there are two major problems: on one hand, the number of passengers has increased as well because of population growth. On the other hand, passengers' expectations of comfort levels have also increased. Therefore, any changes in the public transportation system have to overcome these two challenges along with accessibility in order to encourage personal car users to change their choice of transportation.

Finally, it is believed that the TMATN is a complex network with complex users, but it seems that the network better responds to policies exerted on users than on vehicles. Additional proof for this suggestion will be published soon by the authors. Thus, it is suggested that in modeling the TMATN, focus should be on users and their personal characteristics; characteristics which encourage users to use public transportation instead of personal vehicles. It is also important that the focus should be both on modeling user behavior and variables affecting policies exerted on such users. 


\section{LIST OF FIGURES AND TABLES:}

Fig. 1. Gasoline price in TMA since 1997

Rys. 1. Cena benzyny w TMA od 1997 roku

Fig. 2. Number of new registered personal Vehicles in TMA

Rys. 2. Liczba nowych samochodów osobowych zarejestrowanych w TMA

Fig. 3. Tehran Metropolitan Area

Rys. 3. Obszar Metropolitalny Teheranu

Fig. 4. APM station's data (yearly fluctuations)

Rys. 4. Dane stacji APM (roczne wahania)

Fig. 5. "Bazar" APM station's data, P2-P5 periods

Rys. 5. Dane stacji APM „Bazar”, okresy P2-P5

Fig. 6. "Bazar" APM station's data, P1\&P5 periods

Rys. 6. Dane stacji APM „Bazar”, okresy P1 i P5

Fig. 7. "Fatemi" APM station's data, P2-P5 periods

Rys. 7. Dane stacji APM „Fatemi”, okresy P2-P5

Fig. 8. "Bazar" compared to "Fatemi" APM station's data on workdays, P2-P4 periods

Rys. 8. „Bazar” w porównaniu z danymi stacji „Fatemi” w dniach pracy, okresy P2-P4

Fig. 9. "Poonak" APM station's data, P1-P5 periods

Rys. 9. Dane stacji APM „Pooonak”, okresy P1-P5

Fig. 10. “Aghdasyeh” APM station's data, P1-P5 periods

Rys. 10. Dane stacji APM „Aghdasyeh”, okresy P1-P5

Fig. 11. "Aghdasyeh" APM station's data, P4, P6\&P7 periods

Rys. 11. Dane stacji APM „Aghdasyeh”, okresy P4, P6 i P7

Fig. 12. "Park-e-Roz" APM station's data, P1-P5 periods

Rys. 12. Dane stacji APM „Park-e-Roz”, okresy P1-P5

Fig. 13. "Shahr-e-Rey" APM station's data, P1-P5 periods

Rys. 13. Dane stacji APM „Shahr-e-Rey”, okresy P1-P5 


\section{REFERENCES}

1. Vafa-Arani, H., et al., A system dynamics modeling for urban air pollution: A case study of Tehran, Iran. Transportation Research Part D: Transport and Environment, 2014. 31: p. 21-36.

2. Ahanchian, M. and J.B.M. Biona, Energy demand, emissions forecasts and mitigation strategies modeled over a medium-range horizon: The case of the land transportation sector in Metro Manila. Energy Policy, 2014. 66(0): p. 615-629.

3. Davoudpour, H. and M.S. Ahadi, The potential for greenhouse gases mitigation in household sector of Iran: cases of price reform/efficiency improvement and scenario for 2000-2010. Energy Policy, 2006. 34(1): p. 40-49.

4. Alipour, S., et al., Energy and environmental issues in transport sector. International Journal of Environmental Research, 2010. 5(1): p. 213-224.

5. Statistical Centre of Iran. Iran Statistical Year Book. 2012; Available from: www.amar.org.

6. Naddafi, K., et al., Health impact assessment of air pollution in megacity of Tehran, Iran. Journal of Environmental Health Science and Engineering, 2012. 9(1): p. 28.

7. Jamaati, H.R., et al., The effects of air pollution on acute respiratory conditions. Respirology, 2003. 8(2): p. 213-230.

8. Masiol, M., et al., Thirteen years of air pollution hourly monitoring in a large city: Potential sources, trends, cycles and effects of car-free days. Science of The Total Environment, 2014. 494-495: p. 84-96.

9. Han, X. and L.P. Naeher, A review of traffic-related air pollution exposure assessment studies in the developing world. Environment international, 2006. 32(1): p. 106-120.

10. Xia, T., et al., Traffic-related air pollution and health co-benefits of alternative transport in Adelaide, South Australia. Environ Int, 2015. 74: p. 281-90.

11. Shepherd, S.P., A review of system dynamics models applied in transportation. Transportmetrica B: Transport Dynamics, 2014. 2(2): p. 83-105.

12. Sabounchi, N.S., et al., Dynamic simulation modeling and policy analysis of an area-based congestion pricing scheme for a transportation socioeconomic system. Transportation Research Part A: Policy and Practice, 2014. 59(0): p. 357383.

13. Robalino-López, A., A. Mena-Nieto, and J.E. García-Ramos, System dynamics modeling for renewable energy and CO2 emissions: A case study of Ecuador. Energy for Sustainable Development, 2014. 20: p. 11-20.

14. Haghshenas, H., M. Vaziri, and A. Gholamialam, Evaluation of sustainable policy in urban transportation using system dynamics and world cities data: A case study in Isfahan. Cities, 2014.

15. Wang, J., H. Lu, and H. Peng, System Dynamics Model of Urban Transportation System and Its Application. Journal of Transportation Systems Engineering and Information Technology, 2008. 8(3): p. 83-89.

16. Haghani, A., S.Y. Lee, and J.H. Byun, A system dynamics approach to land use/transportation system performance modeling Part I: Methodology. Journal of Advanced Transportation, 2003. 37(1): p. 1-41.

17. Abbas, K.A. and M.G.H. Bell, System dynamics applicability to transportation modeling. Transportation Research Part A: Policy and Practice, 1994. 28(5): p. 373-390.

18. TCTTC, Tehran Transportation statistics. 2013.

19. Hajihosseinlou, M. and S. Kabiri, Evaluating the effect of vehicles on air pollution and defining the main pollutant in modeling and validating transportation networks, in 14th International Conference on Traffic and Transportation Engineering. 2015: Tehran, Iran.

20. Keyhani, A., et al., An assessment of wind energy potential as a power generation source in the capital of Iran, Tehran. Energy, 2010. 35(1): p. 188-201.

21. Rashidi, M. and M. Massoudi, A study of the relationship of street level carbon monoxide concentrations to traffic parameters. Atmospheric Environment (1967), 1980. 14(1): p. 27-32.

22. Sarabi, E.R., An analysis to energy consumption rate in road transportation sector of Iran and introduction policies of fuel consumption management in recent years. Procedia Engineering, 2011. 21(0): p. 989-996.

23. Deakin, E., et al., Transportation Pricing Strategies for California: An Assessment of Congestion, Emissions, Energy. And Equity Impacts. 1996, University of California Transportation Center. 


\section{DŁUGOTERMINOWE REAGOWANIE NA ZANIECZYSZCZENIA POWIETRZA W POLITYKACH TRANSPORTOWYCH OBSZARU METROPOLITALNEGO TEHERANU}

Słowa kluczowe: sieci transportowe, zanieczyszczenie powietrza, zachowania użytkowników, analiza polityki

\section{STRESZCZENIE:}

Nie można zignorować zależności ludzi od sieci motoryzacyjnych, a tym samym zarządzanie tymi sieciami jest ważnym zadaniem w odpowiedniej eksploatacji tych sieci. Jednak w ostatnich latach szybkość urbanizacji rzeczywiście stworzyła wiele obaw dotyczących warunków zdrowotnych panujących na samej Ziemi i dotyczących ludzi, którzy na niej żyją, a konkretnie zanieczyszczeń powietrza. Takie obawy doprowadziły do stworzenia różnych polityk, które obecnie obowiązują w sieciach transportowych. Jednak sieci transportowe reagują różnie na obowiązujące polityki.

Obszar Metropolitalny Teheranu (TMA, Tehran Metropolitan Area) - stolicy Iranu - jest jedną z najbardziej złożonych sieci ze złożonymi użytkownikami, która doświadczyła wielu polityk w ciągu ostatnich dziesięcioleci. Obecny plan, zmieniony prawie dziewiętnaście razy w zakresie obejmującego obszaru, floty i harmonogramu od 1978 roku, głównie ogranicza dostępność samochodów osobowych. Został on wprowadzony w 2004 roku. „Polityka Ograniczenia Ruchu w Dniach Parzystych i Nieparzystych” Odd-Even Day (Odd-Even Day Traffic Restriction Policy, OETRP) i „Polityka Stref Zastrzeżonych” (Restricted Area Policy, RAP) to dwa główne plany obowiązujące obecnie w Centralnej Dzielnicy Biznesowej (Central Business District, CBD). Ponad 40 procent codziennych podróży osób dojeżdżających przesuwa się w kierunku centrum miasta w porannych godzinach szczytu, dlatego większość polityk zarządzania transportem koncentruje się na dzielnicy CBD. Region cierpi zarówno z powodu korków, jak i zanieczyszczenia powietrza na skutek codziennych podróży, z czego to drugie stało się w ostatnich latach centrum wzmożonej uwagi. W niniejszej pracy poddano badaniu niektóre z tych polityk i ich wpływ na zanieczyszczenie powietrza. Celem jest znalezienie tych zmiennych, które mają największy wpływ na konkretne modele transportu i na czym powinny się koncentrować nowe polityki.

Prawie dziesięć lat upłynęło od czasu ostatniej zmiany obowiązujących głównych ograniczeń ruchu dotyczących sieci TMATN. Nowe zarejestrowane wartości pokazują, że dzielnica CBD osiągnęła stały poziom stężenia zanieczyszczeń. Tym samym w celu zmniejszenia zanieczyszczenia powietrza generowanego przez sektor transportu w tym regionie, należy opracować nowe polityki. Istnieje ponad 30 stacji Monitorowania Zanieczyszczenia Powietrza (Air Pollution Monitoring, APM) zainstalowanych w różnych regionach obszaru TMA przez Agencję Kontroli Jakości Powietrza w Teheranie (Tehran Air Quality Control Agency, TAQCA) we współpracy z Wydziałem Środowiska w Teheranie (Tehran Department of Environment, TDOE), które zapisują stężenie zanieczyszczeń co godzinę. Spośród nich wybrano sześć stacji do przeprowadzenia szczegółowego przeglądu danych: stacje „Bazar”, „Fatemi”, „Poonak”, „Aghdasyeh”, „Park-e-Roz” i „Shahr-e-Rey”. Przeanalizowano długoterminowe zmiany tych stacji między 1996 a 2013 (w miarę dostępności), aby sprawdzić, czy można było rozpoznać parametry wpływające.

Ponieważ stacje APM zarejestrowały różne stężenia zanieczyszczeń, należało wybrać jedną do dalszej analizy. W niniejszej pracy wybrano tlenek węgla (CO) jako substancję zanieczyszczającą środowisko z dwóch powodów; dłuższej zapisanej historii danych oraz, co ważniejsze, bezpośredniego związku między stężeniami CO a natężeniem ruchu. Inne substancje zanieczyszczające środowisko, takie jak Cząstki Stałe (Particulate Matters, PM) pochodzą z innych źródeł niż pojazdy sieci transportowej, np. parki przemysłowe i fabryki, które otaczają obszar metropolitalny. 
Krótko wyjaśniono parametry wpływające na zanieczyszczenie powietrza i stężenia zanieczyszczeń, takie jak warunki meteorologiczne, parametry społeczno-gospodarcze i dni wolne od pracy. Wzięto pod uwagę warunki meteorologiczne, ponieważ obszar TMA rzeczywiście doświadcza pełnej zmiany sezonowej przez cały rok - od gorącego lata do mroźnej zimy. Parametry społeczno-ekonomiczne były rzeczywiście przedmiotem obaw, ponieważ z jednej strony ruch lepszych pojazdów, które emitują mniej zanieczyszczeń, ma bezpośredni związek z siłą nabywczą mieszkańców, którzy stanowią szeroką gamę w obszarze TMA. Z drugiej strony zmiany cen paliw w obszarze TMA wykazały zdolność zmiany wyborów użytkowników, która jednak przez większość czasu jest tymczasowa. Oprócz cen zakupu mocy i paliwa, zmienna „ilość właścicieli samochodów” również odgrywa ważną rolę w obszarze TMA, ponieważ średnio 300000 nowych pojazdów jest rejestrowanych w obszarze TMA.

Różnice danych w różnych częściach obszaru TMA pokazują, że każdy region ma swoje własne cechy, które w niektórych przypadkach różnią się znacząco w porównaniu z innymi regionami. Jedną z głównych zmiennych, która była w stanie ograniczyć zanieczyszczenie powietrza, okazała się być cena paliwa. Niemal wszystkie części miasta, zarówno biedne i bogate, choć nie jednakowo, odpowiedziały na wzrost cen paliw.

Wyniki pokazują, że zamożni mieszkańcy miasta wolą używać swoich samochodów osobowych, kiedy widzą obniżenie poziomu komfortu systemu transportu publicznego. Innymi słowy, w ostatnich latach czas jazdy stał się mniej ważny. Kierowcy zazwyczaj nie męczą się jazdą samochodami na zatłoczonych autostradach. Takie zachowanie jest również z pewnością konsekwencją złego systemu transportu publicznego, który nie jest w stanie zaoferować poziomu komfortu będącego w stanie przyciągnąć pasażerów. Poza tym wysoka liczba właścicieli pojazdów i jej wzrost w ostatniej dekadzie doprowadziły do zmiany zachowania kierowców. Wydaje się, że ze względu na zły system transportu publicznego, jazda samochodami osobowymi stała się dla kierowców bardziej atrakcyjna. Niestety zmiany danych w obszarach mniej zanieczyszczonych wykazują lekko rosnącą tendencję. Powód może leżeć w tym, że dzielnica CBD przeżywa rodzaj ekspansji, która może nie być dobrze zorganizowana i może w najbliższej przyszłości doprowadzić do kryzysu w jakości zanieczyszczenia powietrza.

Z pewnością w ostatnich latach poziom komfortu oferowanego pasażerom przez transport publiczny wzrasta. Jednak istnieją dwa główne problemy z tym związane; liczba pasażerów wzrosła również z powodu wzrostu liczby ludności i oczekiwania pasażerów co do poziomu komfortu również wzrosły. Zatem zmiana systemu transportu publicznego musi przezwyciężyć te dwa wyzwania wraz z dostępnością w celu zachęcenia użytkowników samochodów osobowych do zmiany środka transportu. Wreszcie uważa się, że sieć TMATN składa się ze złożonych użytkowników, ale wydaje się, że sieć lepiej odpowiada na polityki wpływające na użytkowników, a nie na pojazdy. Toteż sugeruje się, że podczas modelowania sieci TMATN należy skupić się na użytkownikach i ich cechach osobistych - cechach, które zachęcają użytkowników do korzystania z transportu publicznego zamiast samochodów osobowych. Ważne jest również skupienie się zarówno na modelowaniu zachowań użytkowników, jak i zmiennych wpływających na polityki oddziaływujące na takich użytkowników. 
